\title{
Foraging of Great Kiskadees (Pitangus sulphuratus) and food items offered to nestlings in the Pantanal
}

\author{
Munin, RL. ${ }^{a *}$, Fischer, E. ${ }^{b}$ and Longo, JM. ${ }^{a}$ \\ aPrograma de Pós-graduação em Ecologia e Conservação, Universidade Federal de Mato Grosso do Sul - UFMS, \\ CEP 79070-900, Campo Grande, MS, Brazil \\ ${ }^{\text {b} C e n t r o ~ d e ~ C i e ̂ n c i a s ~ B i o l o ́ g i c a s ~ e ~ d a ~ S a u ́ d e, ~ U n i v e r s i d a d e ~ F e d e r a l ~ d e ~ M a t o ~ G r o s s o ~ d o ~ S u l ~-~ U F M S, ~}$ \\ CEP 79070-900, Campo Grande, MS, Brazil \\ *e-mail: robertomunin@yahoo.com.br
}

Received July 1, 2011 - Accepted October 6, 2011 - Distributed August 31, 2012

(With 1 figure)

\begin{abstract}
Feeding of Pitangus sulphuratus (Tyrannidae) nestlings have been poorly studied. Here we describe the foraging behavior of a P. sulphuratus pair and the searching and offering time of food items to nestlings in the Pantanal, Brazil. Data collection was carried out over 25 days on the outskirts of the Base de Estudos do Pantanal building, inhabited by insectivorous bats. Records were based on direct observations with the help of binocular. The pair required little time for searching for small insects and fruits, but these items comprised a little amount of food per event of capture. Some large prey was more time-costly for searching, but the long period that these food items were offered to nestlings overcompensated the searching time. Considering the time of feeding nestlings (benefit) in relation to the searching time by the parents (cost), bats and snails are the most advantageous items for $P$. sulphuratus parents feeding nestlings at the study site.
\end{abstract}

Keywords: feeding behavior, foraging strategy, nestling diet, parental care, predation.

\section{Forrageamento de bem-te-vis (Pitangus sulphuratus) e itens alimentares oferecidos para ninhêgos no Pantanal}

\section{Resumo}

A alimentação de ninhêgos de Pitangus sulphuratus (Tyrannidae) tem sido pouco estudada. Descrevemos, neste estudo, o comportamento de forrageamento de um casal de P. sulphuratus e o tempo para busca e oferta de itens aos ninhêgos, no Pantanal, Brasil. A coleta de dados foi realizada durante 25 dias nas proximidades do prédio da Base de Estudos do Pantanal, habitada por morcegos insetívoros. Os registros foram baseados em observações diretas com auxílio de binóculo. O casal demandou pouco tempo de busca para a captura de pequenos insetos e frutos, porém esses itens representaram pouca quantidade de alimento por evento de captura. Algumas presas grandes demandaram mais tempo para busca, mas o longo período que esses itens foram oferecidos aos ninhêgos sobrecompensou o tempo de busca. Considerando-se o tempo de alimentação dos ninhêgos (benefício) em relação ao tempo de busca pelos pais (custo), morcegos e caramujos são itens mais vantajosos para os pais de P. sulphuratus alimentar ninhêgos no local de estudo.

Palavras-chave: comportamento alimentar, cuidado parental, dieta de ninhêgos, estratégia de forrageamento, predação. 


\section{Introduction}

Pitangus sulphuratus (Linnaeus, 1766) is a very common tyrant flycatcher which inhabits several wild and human modified habitats in Brazil (Ruszczyk et al., 1987; Fischer et al., 2010). It can forage over variable substrates, such as in the air, on foliage, branches, ground or water, preying on small vertebrates and invertebrates or feeding on fruits and flowers (Latino and Beltzer, 1999; Gabriel and Pizo, 2005; Fischer et al., 2010). However, $P$. sulphuratus behavior and manipulation of food items offered for nestlings have been poorly studied (Lago-Paiva, 1996; Argel-de-Oliveira et al., 1998; Toledo et al., 2005). Feeding nestlings demands large amounts of parent's time and energy, spent mainly when searching and capturing preys (Mock, 1991). One way to maximize the cost-benefit budget is to search for large prey, therefore reducing the number of foraging bouts and increasing time of nestling attendance (Fitzpatrick, 1981; Smith et al., 1988). We describe here the foraging behavior of, and food items used by, $P$. sulphuratus parents feeding nestlings in the Pantanal floodplain, southwestern Brazil. In addition, we describe the time cost-benefit of the parents for feeding nestlings associated to different food items, based on the time for searching and capturing a given item (cost) and the time that each item conferred for feeding nestlings (benefit).

\section{Methods}

One banded pair of $P$. sulphuratus was studied over 25 days at the beginning of the reproductive season (October and November) on the outskirts of the Base de Estudos do Pantanal $\left(19^{\circ} 34^{\prime} \mathrm{S}\right.$ and $\left.57^{\circ} 01^{\prime} \mathrm{W}\right)$, Universidade Federal de Mato Grosso do Sul, southern Pantanal, Brazil. The mean annual temperature is $25^{\circ} \mathrm{C}$ and the mean annual rainfall is $1000 \mathrm{~mm}$, with a dry season from April to September and a wet season from October to March. Vegetation comprises deciduous and semi-deciduous forest patches and open fields (Araujo and Sazima, 2003). The $P$. sulphuratus pair constructed a nest $4 \mathrm{~m}$ above ground on a Coccoloba cujabensis Wedd. (Polygonaceae) fruiting tree. Based on occasional observations there were at least two nestlings. Pitangus sulphuratus' foraging behavior and food items were recorded between 0700 and 1200 hours, except some additional events of predation on bats which were unsystematically recorded in the afternoon. Data were collected by direct observations with the help of binoculars, and food items were identified based on observations and collection of prey parts discarded under the nest.

Capture behavior of $P$. sulphuratus was classified according to Fitzpatrick (1980): Aerial Hawking, when aerial prey is pursued and captured in flight; Perch-toWater Sallying Surface Gleaning, the approach flight is directed toward a position several centimeters over the surface prey, which is picked from the water with a smooth downward head motion, during a brief hover; Perch-toWater Sallying Dive, prey is captured in the bill with the bird's head submerged and the bird returns to the perch to handle prey; Perch-gleaning, when stationary prey is taken from the substrate while the bird remains perched; Ground Sally-gleaning, prey is found while the bird is on the ground and it is picked from the substrate during a short jump or flight; Outward Hover-gleaning, the approach flight is rapid and direct, and prey is snatched from an exposed surface during a short hover in which the bird may still be moving forward.

We additionally recorded the time for searching and capturing food items, and the time that each captured item contributed to parental attendance for feeding nestlings (cf. Gabriel and Pizo, 2005; Bañbura et al., 1999). We estimated time benefit:cost ratios for the parental birds according to different food types offered for feeding nestlings. The average time for searching and capturing each type of food was assigned as cost, and the average time each item contributed for feeding nestlings was assigned as benefit.

\section{Results}

During the entire period of observations, the nest was never left alone, as at least one parental bird stayed in the nest or perched nearby. The parents alternated in the functions of guarding the nest and foraging for feeding the nestlings. One parent commonly did three or more subsequent foraging bouts for feeding nestlings, and then it took its turn in the nest. We recorded 122 events of capture of food items, of which 68 were cases of predation on animals and 38 were events of fruit collecting (Table 1). Aerial Hawking was the most common (41/106) method of prey capture used by $P$. sulphuratus parents and was only used for capturing insects. The second most common (38/106) method, Perch-gleaning, was only used for fruit removal. Perch-to-Water Sallying Surface Gleaning (11/106) and Perch-to-Water Sallying Dive (4/106) were the methods used for capturing six types of food items. Lizards were captured by Outward Hover-gleaning method (2/106), and bats were captured by Ground Sally-gleaning method (10/106).

The time spent by the parents while searching for food was higher when preying on water bug (Belostomatidae), frog (Physalaemus albonotatus; Leptodactylidae), aquatic invertebrates, dragonflies and bats (Myotis sp.) than when preying on other items or consuming fruits (Figure 1). Dragonflies, bats, frogs, snail and water bug were handled by $P$. sulphuratus parents before feeding the nestlings, but other insects and C. cujabensis fruits were not. Handling consisted of killing and dilacerating the prey by beating it against a tree branch, near the nest. This behavior was repeated by $P$. sulphuratus until all edible prey parts were consumed by the nestlings. Time for feeding nestlings was markedly high when food items were bats, frogs or snail (Figure 1).

\section{Discussion}

Our results support that the diet of $P$. sulphuratus nestlings at the study site was mainly based on animal material, both in quantity and richness of food types, whereas plant 


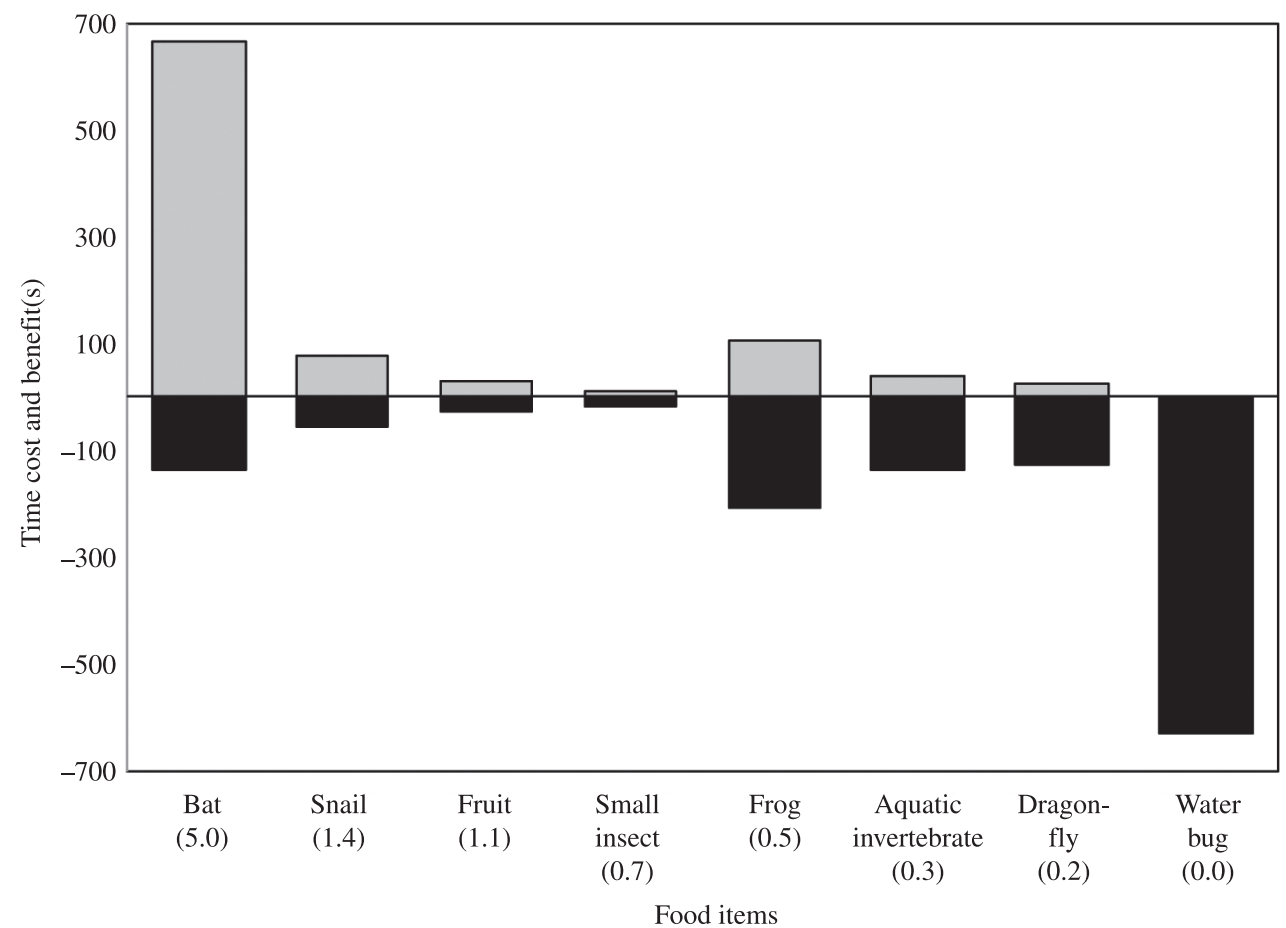

Figure 1. Average time cost for searching and capturing eight food types (expressed as negative values; black bars), and average time for feeding nestlings (assigned as benefit; gray bars), by Great Kiskadees parents in the Pantanal. Food items are arranged in decreasing order of benefit: cost ratios (values within brackets).

Table 1. Foraging behavior (cf. Fitzpatrick, 1980) of Great Kiskadees parents for searching and capturing of 10 food types offered to nestlings in the Pantanal.

\begin{tabular}{lcc}
\hline \multicolumn{1}{c}{ Food item } & Events $(\mathbf{N})$ & Capture behavior \\
\hline Small insects & 41 & Aerial Hawking \\
Fruits (Coccoloba cujabensis) & 38 & Perch-gleaning \\
Bats (Myotis spp.) & 10 & Ground Sally-gleaning \\
Aquatic invertebrates & 8 & Perch-to-Water Sallying Surface Gleaning \\
Dragonflies & 2 & Perch-to-Water Sallying Surface Gleaning \\
Fishes & 2 & Perch-to-Water Sallying Dive \\
Lizards (Tropidurus sp.) & 2 & Outward Hover-gleaning \\
Snail (Pomacea sp.) & 1 & Perch-to-Water Sallying Dive \\
Frog (Physalaemus albonotatus) & 1 & Perch-to-Water Sallying Surface Gleaning \\
Water bug (Belastomatidae) & 1 & Perch-to-Water Sallying Dive \\
Unknown & 16 & \\
$\Sigma$ & 122 & \\
\hline
\end{tabular}

material comprised only fruit of $C$. cujabensis. Likewise, Argel-de-Oliveira et al. (1998) reported that nestlings of P. sulphuratus were mainly fed on animal material in an urban site. Additional available data on nestlings' diet include the consumption of the frog Scinax nasicus, recorded at our study site (Toledo et al., 2005). The predominance of Aerial Hawking and Perch-gleaning behaviors over other ones is a common pattern among Tyrannidae species (Gabriel and Pizo, 2005; Lopes et al., 2005; Fitzpatrick, 1980). At the study site, the high frequency of these two behaviors was likely related to the small size of insects and $C$. cujabensis fruit, which impels the birds to carry out multiple events of capture to achieve a certain food amount for feeding nestlings. Perch-to-Water Sallying Surface Gleaning and Perch-to-Water Sallying Dive are used for capturing most of the food items by the P. sulphuratus parents, probably explained by the great variety of water environments in the Pantanal (Junk et al., 2006). Ground Sally-gleaning was especially used for preying on bats, 
captured in their roost in fissures under a building's floor slabs (Fischer et al., 2010).

Small insects and fruit required little time for searching, and are those items that $P$. sulphuratus parents spent less time on feeding nestlings in the Pantanal, indicating a low time cost for attaining the resource but also a low time benefit for attending the nestlings per event of capture. Predation on dragonflies does not seem advantageous, as it required long searching time relative to time feeding nestlings. Water bug was a common prey of P. sulphuratus in Argentina (Latino and Beltzer, 1999), but it was rarely captured at our study site and the only preyed individual was not offered to the nestlings. Based on time of searching in relation to time of feeding nestlings, bats and snails seem to present the best cost-benefit relationship for $P$. sulphuratus parents at the study site. The time effort when searching for this large prey may be advantageous for $P$. sulphuratus parents as they can attend nestlings for longer. It tends to reduce the number of foraging bouts needed to supply the nestlings and to propitiate increased time to protect nestlings against predators (Marini et al., 2009). As bats so far appear to be the most advantageous item for feeding nestlings, the vulnerability of bats inhabiting the BEP building (Fischer et al., 2010) could explain why $P$. sulphuratus parents decided to nest there.

Acknowledgements - To anonymous referees for comments which improved the manuscript, to Conselho Nacional de Desenvolvimento Científico e Tecnológico (CNPq) for grants to R. L. Munin and E. Fischer, and to Coordenação de Aperfeiçoamento de Pessoal de Nível Superior (CAPES) for a grant to J. M. Longo.

\section{References}

ARAUJO, AC. and SAZIMA, M., 2003. The assemblage of flowers visited by hummingbirds in the "capões" of Southern Pantanal, Mato Grosso do Sul, Brazil. Flora, vol. 198, no. 6, p. 427-435. http://dx.doi.org/10.1078/0367-2530-00116

ARGEL-DE-OLIVEIRA, MM., CURI, NA. and PASSERINI, T., 1998. Alimentação de um filhote de bem-te-vi, Pitangus sulphuratus (Linnaeus, 1766) (Passeriformes: Tyrannidae), em ambiente urbano. Revista Brasileira de Zoologia $=$ Zoologia vol. 15 , no. 4 , p. 1103-1109.

BAÑBURA, J., LAMBRECHTS, MM., BLONDEL, J., PERRET, P. and CARTAN-SONSOURCE, M., 1999. Handling Time of Blue Tit Chicks: Constraints and Adaptation to Different Prey. Journal of Avian Biology, vol. 30, no. 3, p. 263-270. http://dx.doi. org/10.2307/3677352
FISCHER, E., MUNIN, RL., LONGO, JM., FISCHER, W. and SOUZA, PR., 2010. Predation on bats by Great Kiskadees. Journal of Field Ornithology, vol. 81, no. 1, p. 17-20. http:// dx.doi.org/10.1111/j.1557-9263.2009.00256.x

FITZPATRICK, JW., 1980. Foraging behavior of neotropical tyrant flycatchers. Condor, vol. 82, no. 1, p. 43-57. http://dx.doi. org/10.2307/1366784

-, 1981. Search strategies of tyrant flycatchers. Animal Behaviour, vol. 29, p. 810-821. http://dx.doi.org/10.1016/S0003-3472(81)800152

GABRIEL, VA. and PIZO, MA., 2005. Foraging behavior of tyrant flycatchers (Aves, Tyrannidae) in Brazil. Revista Brasileira de Zoologia $=$ Zoologia, vol. 22, no. 4, p. 1072-1077.

JUNK, WJ., CUNHA, CN., WANTZEN, KM., PETERMANN, P., STRÜSSMANN, C., MARQUES, MI. and ADIS, J., 2006. Biodiversity and its conservation in the Pantanal of Mato Grosso, Brazil. Aquatic Sciences, vol. 68, no. 3, p. 278-309. http://dx.doi. org/10.1007/s00027-006-0851-4

LAGO-PAIVA, C., 1996. Cavity nesting by Great Kiskadees Pitangus sulphuratus: adaptation or expression of ancestral behavior? Auk, vol. 113, no. 4, p. 953-955.

LATINO, S. and BELTZER, A., 1999. Ecología trófica del benteveo Pitangus sulphuratus (Aves: Tyrannidae) en el valle de inundación del río Paraná, Argentina. Orsis, vol. 14, p. 69-78.

LOPES, LE., FERNANDES, AM. and MARINI, MA., 2005. Predation on vertebrates by neotropical passerine birds. Lundiana, vol. 6 , no. 1, p. 57-66.

MARINI, MA., SOUSA, NOM., BORGES, FJA. and SILVEIRA, MB., 2009. Biologia reprodutiva de Elaenia cristata (Aves: Tyrannidae) em cerrado do Brasil Central. Neotropical Biology and Conservation, vol. 4, p. 3-12.

MOCK, PJ., 1991. Daily allocation of time and energy of Western Bluebirds feeding nestlings. Condor, vol. 93, p. 598-611. http:// dx.doi.org/10.2307/1368192

RUSZCZYK, A., RODRIGUES, JJS., ROBERTS, TMT., BENDATI, MMA., DEL-PINO, RS., MARQUES, JVC. and MELO, MTQ., 1987. Distribution patterns of eight bird species in the urbanization of Porto Alegre, Brazil. Ciência e Cultura, vol. 39, p. 14-19.

SMITH, HG., KÄLLANDER, H., FONTELL, K. and LJUNGSTRÖM, M., 1988. Feeding frequency and parental division of labour in the double-brooded great tit Parus major: Effects of manipulating brood size. Behavioral Ecology and Sociobiology, vol 22, no. 6, p. 447-453. http://dx.doi.org/10.1007/BF00294983

TOLEDO, LF., WOHEL-JUNIOR, G., WOHEL, E. and PRADO, CPA., 2005. Scinax nasicus, Hyla albomarginata, Hyla bischoff, and Phyllomedusa distincta (Tree Frogs): avian predation. Herpetological Bulletin, vol. 92, p. 31-32. 